\title{
Effectiveness and Safety of Insulin Glulisine When Initiating Supplementary Prandial Insulin Treatment (SIT) in Insulin-Naïve Patients with Type 2 Diabetes: The Observational IGLU-SIT Study
}

\author{
Martin Pfohl · Jochen Seufert • Anja Borck • Peter Bramlage • \\ Thorsten Siegmund
}

Received: November 12, 2020 / Accepted: January 6, 2021 / Published online: February 5, 2021

(c) The Author(s) 2021

\section{ABSTRACT}

Introduction: The IGLU-SIT study documented the effectiveness of initiating supplementary prandial insulin treatment (SIT) with insulin glulisine after failure of oral antidiabetic drugs alone in patients with type 2 diabetes (T2DM) in a real-world setting in Germany.

Methods: The IGLU-SIT study was an open-label, prospective, multicentre, non-interventional study with an observation period of $12 \pm 1$ months. The primary objective was to determine the proportion of patients reaching

\footnotetext{
M. Pfohl ( $\square)$

Department of Internal Medicine I, BethesdaHospital Duisburg, Evangelisches Krankenhaus Bethesda, Duisburg, Germany e-mail: mnpfohl@o2online.de

J. Seufert

Division of Endocrinology and Diabetology, Department of Medicine II, Faculty of Medicine, Medical Centre, University of Freiburg, Freiburg, Germany
}

A. Borck

Sanofi-Aventis Deutschland GmbH, Berlin,

Germany

P. Bramlage

Institute for Pharmacology and Preventive

Medicine, Cloppenburg, Germany

T. Siegmund

Division for Endocrinology, Diabetology and

Metabolism, Isar Clinic, Munich, Germany their pre-defined glycosylated haemoglobin (HbA1c) goal at 3, 6, 9 and 12 months. Selected secondary objectives were absolute change in HbA1c, a 7-point blood glucose profile, and rate of hypoglycaemia. Data were evaluated overall and by age group $(<65,65-74$ and $\geq 75$ years). Results: Overall, 215 patients with T2DM were observed in 64 centres. Baseline $\mathrm{HbA1c}$ was $8.3 \%$, and mean HbA1c target was $6.8 \%$ (baseline $8.1 \%$ and target $6.9 \%$ in patients $\geq 75$ years). Individual HbA1c target attainment in patients peaked at 38.9\% (95\% confidence interval [CI] 32.1-46.1\%) after 12 months; this was $45.9 \%$ in patients aged $\geq$ 75 years. The mean HbA1c reduction was $1.12 \pm 1.05 \%(p<0.0001)$ with only minor differences by age group. A 7-point blood glucose profile revealed significant reductions $(p<0.0001)$ at all time-points. The rate of confirmed symptomatic hypoglycaemia was $2.2 \%$ (95\% CI 0.7-5.1) during the 12-month follow-up; rates were increased in patients aged $\geq 75$ years $(7.0 \%$; $95 \%$ CI $1.5-19.1)$ as were the rates of adverse events (17.8 vs. $6.1 \%)$.

Conclusion: Initiating SIT with insulin glulisine is an appropriate treatment option in patients whose T2DM is insufficiently controlled. Particular attention should be paid to elderly patients in whom higher attainment rates of treatment target were associated with adverse events.

Trial Registration: https://awbdb.bfarm.de; Identifier: 6819; Date of registration: 23.06.2016 
Keywords: Blood glucose; Diabetes; HbA1c; Hypoglycaemia; Insulin

\section{Key Summary Points}

Why carry out this study?

Relatively limited information is available on the performance of insulin glulisine in the real-world setting supplementary prandial insulin treatment (SIT) initiation in patients with type 2 diabetes mellitus (T2DM).

The IGLU-SIT study documented the effectiveness of initiating SIT with insulin glulisine after failure of oral antidiabetic drugs alone in patients with T2DM in a real-world setting in Germany.

What was learned from this study?

Initiating SIT with insulin glulisine is an appropriate treatment option in insufficiently controlled patients with T2DM.

Particular attention should be paid to elderly patients in whom higher rates of attainment of the treatment target were associated with higher rates of hypoglycaemia and adverse events.

\section{DIGITAL FEATURES}

This article is published with digital features, including a summary slide, to facilitate understanding of the article. To view digital features for this article go to https://doi.org/10.6084/ m9.figshare.13526468.

\section{INTRODUCTION}

Insulin glulisine is a rapid-acting insulin analogue with rapid absorption and onset of action following subcutaneous injection. It is used to cover mealtime insulin requirements in patients with diabetes. Based on its zinc-free formulation, insulin glulisine has a faster onset of action than insulin lispro and insulin aspart [1-3].

The initiation of insulin is considered to be the next step for patients with type 2 diabetes (T2DM) following the failure of oral antidiabetic drugs (OADs) to reach a target glycosylated haemoglobin A1c (HbA1c) level, and is also used as first-line therapy in some persons with uncontrolled diabetes. Insulin can be introduced either as basal insulin (basal-supported oral treatment [BOT]) or as a supplementary insulin therapy at mealtimes (SIT) [4]. Little information is currently available on the performance of insulin glulisine during initiation of SIT in the real-world setting in patients with T2DM. The objective of this non-interventional observational study, therefore, was to document the effectiveness of initiating insulin treatment in a SIT regimen with insulin glulisine in patients with T2DM (in addition to OADs) in a real-world setting in Germany and over a period of 52 weeks and to analyse the change in benefits and risks with age.

There is always a potential for an altered benefit-risk profile of antidiabetic drugs in the elderly. These patients tend to have lower HbA1c values, but are inclined to higher rates of hypoglycaemia and adverse events [5-7]. As such, an addition aim was to explore how age affected the benefit-risk profile of insulin glulisine in the context of this study.

\section{METHODS}

\section{Study Design}

The IGLU-SIT study was an open-label, prospective, multicentre, non-interventional observational study with 12 months of observation. Participating physicians were diabetologists, internists, general practitioners and family physicians in Germany. The registry protocol was approved by the University of Freiburg, Germany, and was carried out in accordance with the Declaration of Helsinki and its amendments. Only people who provided 
written informed consent to participate were included.

\section{Patient Selection}

The inclusion criteria was (1) adult ( $\geq 18$-yearold) patient with insulin-naive T2DM with documented poor glycaemic control on OADs $(\mathrm{HbA} 1 \mathrm{c}>7.0 \% \quad$ and $\leq 10.0 \% \quad[>53.0$ and $\leq 85.8 \mathrm{mmol} / \mathrm{mol}]$ ); (2) patient's physician had made the decision to add insulin glulisine to the patient's diabetes therapy at their three main meals no earlier than 2 weeks prior to the documentation; (3) patient's willingness to document a 7-point blood glucose profile. Patients with contraindication against insulin glulisine, who were pregnant, had a current cancer and/or had a history of alcohol or drug abuse were excluded.

\section{Data Collection}

Data were collected at baseline and after a follow-up of 3, 6, 9 and 12 months (with some flexibility according to clinical practice routines). Data were entered into an electronic case report form. A monitoring visit was performed at random at $5 \%$ of the sites. All adverse events (AEs) regardless of intensity and relationship to the drug under observation were collected between baseline and 7 days after the last follow-up visit.

\section{Objectives}

The primary objective was to determine the proportion of patients reaching the pre-defined individual HbA1c target at each of the four follow-up visits. Secondary objectives were to describe (1) the change in HbA1c over time; (2) the time to reach the individual HbA1c target after initiating insulin glulisine; (3) the duration of individual HbA1c target attainment until the first HbA1c measurement that was higher than target $\mathrm{HbA1c}$, or the insulin formulation was switched; (4) the change in the dosage of insulin glulisine; (5) the rate of symptomatic, confirmed (self-monitoring blood glucose [SMBG] value of $\leq 70 \mathrm{mg} / \mathrm{dL} \quad[\leq 3.9 \mathrm{mmol} / \mathrm{L}]$ ) symptomatic, nocturnal (symptomatic or confirmed hypoglycaemia occurring approximately between $10 \mathrm{pm}$ and $6 \mathrm{am}$, while the patient was asleep), severe (assistance of another person required or $\mathrm{SMBG}$ value of $\leq 56 \mathrm{mg} / \mathrm{dL}$ $[\leq 3.0 \mathrm{mmol} / \mathrm{L}])$ and severe nocturnal hypoglycaemia. The rates of (serious) AEs were documented. In a selected subset of analyses, we compared the difference in effectiveness and safety in those with a complete 12-month follow-up to the whole group to see whether the former represent a selection of patients with a particularly good effectiveness/safety ratio. Finally, we stratified the overall patient population by age groups, namely $<65$ years, 65-74 and $\geq 75$ years, to explore the effects of age on treatment outcomes.

\section{Statistics}

Data are presented using descriptive statistics, with categorical variables expressed as frequencies and continuous variables as means \pm standard deviations. For the primary efficacy parameter, response rates were described using frequency distribution, with exact 95\% confidence intervals (CI) calculated according to the Clopper-Pearson method. The time to response was analysed using Kaplan-Meier methods, with reaching the pre-defined individual HbA1c goal for the first time considered to be the event. Median time to response and corresponding 95\% CI were estimated using the Kaplan-Meier method. The duration of response was analysed using the Kaplan-Meier method. End of response was defined as the first measurement of an HbA1c above the pre-defined individual HbA1c goal or the switch to another form of insulin therapy (discontinuation of insulin glulisine). Median duration of response was analysed using the Kaplan-Meier method. A $p$ value of $<0.05$ was considered to be significant with no adjustment for multiple testing. All analyses were performed using Statistical Analysis System version 9.4 (SAS Institute, Cary, NC, USA). 


\section{RESULTS}

For this analysis, data were collected at 64 sites in Germany, for a total of 301 patients with T2DM between June 2016 and August 2018 (Fig. 1). Because 53 patients received no insulin glulisine and a further 33 patients did not comply with the inclusion and exclusion criteria, the full analysis set (FAS) comprised 215 patients.

\section{Effectiveness and Safety of Insulin Glulisine}

Patients in the FAS had a mean age of 63.3 years, mean bodyweight of $92.4 \mathrm{~kg}$ and mean body mass index (BMI) of $31.9 \mathrm{~kg} / \mathrm{m}^{2}$; $50.7 \%$ were female (Table 1$)$. The baseline HbA1c value of $8.3 \%(67.2 \mathrm{mmol} / \mathrm{mol})$ and the mean individual target at insulin glulisine initiation was $6.8 \%(50.8 \mathrm{mmol} / \mathrm{mol})$. The majority of patients received metformin $(78.1 \%)$ and/ or dipeptidyl-peptidase 4 (DPP4) inhibitors (46.5\%) as their concomitant OAD treatment. Patients started insulin glulisine at mean doses of 8.6, 6.2 and 7.6 units in the morning, at lunch time and in the evening, respectively (Table 2). Daily doses increased from
$20.4 \pm 11.8$ units at baseline to $33.6 \pm 18.1$ units at 12 months $(p<0.0001$ vs. baseline). Considering the three age groups in terms of weight and insulin doses, it is noticeable that in the beginning all groups started with almost similar mean insulin doses (20.3 units $[<65$ years], 20.5 units [65-74 years], 20.9 units [ $\geq 75$ years]; Table 2), despite the lower mean bodyweight of the older people $(94.5 \mathrm{~kg} \quad[<65$ years], $90.6 \mathrm{~kg}$ [65-74 years], $89.8 \mathrm{~kg}$ [ $\geq 75$ years]; Table 1$)$. The dose adjustment over the course of the study was smallest in the oldest group and, in contrast to the two other groups, was not significant $(p=0.0189$; Table 2).

There was a steady increase in the proportion of patients meeting their pre-defined treatment goal, from $12.6 \%$ at 3 months to $38.9 \%$ (95\% CI 32.1-46.1) at 12 months (Table 3). This corresponded to a mean decrease in HbA1c of $1.12 \%$ $(12.2 \mathrm{mmol} / \mathrm{mol})$ from a baseline value of $8.31 \%(67.3 \mathrm{mmol} / \mathrm{mol} ; p<0.0001)$. The median time to response was 369 days, and $22.1 \%$ of those with an initial response had increased HbA1c values during follow-up or the insulin formulation was switched (Fig. 2). The 7-point blood glucose profile was significantly reduced at 12 months and all time-points (Fig. 3; $p<0.0001)$.

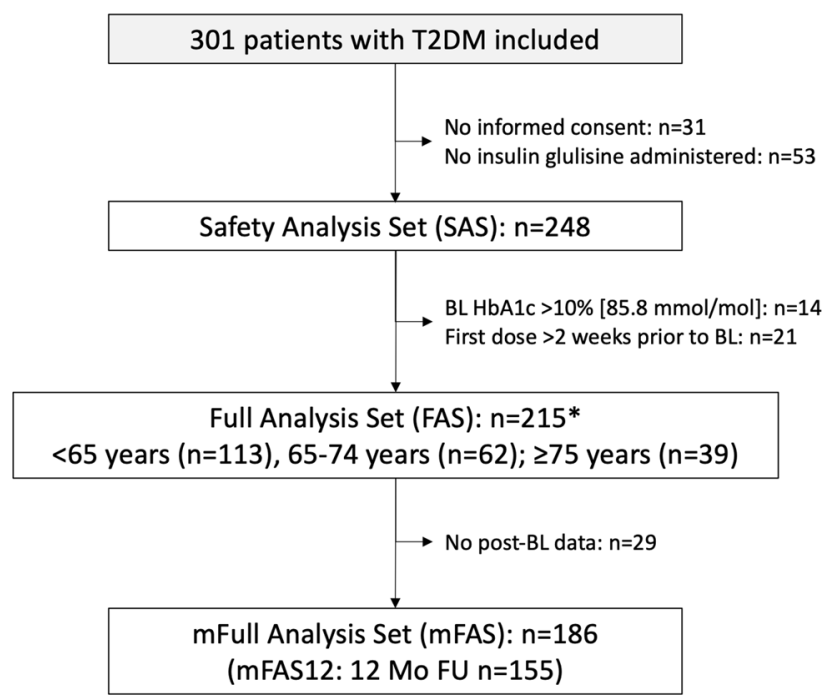

Fig. 1 Patient flow chart. $B L$ Baseline, $H b A 1 c$ glycosylated haemoglobin A1c, $m F A S(12)$ modified full analysis set (with 12 months follow-up [FU]), T2DM type 2 diabetes.
Multiple reasons for exclusion from a particular dataset possible. Asterisk: For one patient no age was available 
Table 1 Patient characteristics

\begin{tabular}{|c|c|c|c|c|c|c|}
\hline \multirow{2}{*}{$\begin{array}{l}\text { Patient } \\
\text { characteristics }\end{array}$} & \multirow{2}{*}{$\begin{array}{l}\text { SAS } \\
(n=248)\end{array}$} & \multicolumn{4}{|l|}{ FAS } & \multirow{2}{*}{$\begin{array}{l}\text { mFAS } 12 \\
(n=155)\end{array}$} \\
\hline & & $\begin{array}{l}\text { Total } \\
(n=215)\end{array}$ & $\begin{array}{l}\text { Patients }<65 \text { years } \\
(n=113)\end{array}$ & $\begin{array}{l}\text { Patients } \\
65-74 \text { years } \\
(n=62)\end{array}$ & $\begin{array}{l}\text { Patients } \\
\geq 75 \text { years }(n=39)\end{array}$ & \\
\hline Age (years) & $63.0 \pm 11.4$ & $63.3 \pm 10.9$ & $54.9 \pm 6.8$ & $69.1 \pm 2.7$ & $78.5 \pm 3.2$ & $64.2 \pm 10.4$ \\
\hline $\begin{array}{l}\text { Female gender, } n \\
\text { (\%) }\end{array}$ & $126(50.8)$ & $109(50.7)$ & $53(46.9)$ & $34(54.8)$ & $22(56.4)$ & 77 (49.4) \\
\hline Body weight (kg) & $92.9 \pm 20.6$ & $92.4 \pm 19.6$ & $94.4 \pm 21.3$ & $90.6 \pm 16.5$ & $89.8 \pm 19.1$ & $92.5 \pm 19.4$ \\
\hline BMI $\left(\mathrm{kg} / \mathrm{m}^{2}\right)$ & $32.0 \pm 6.2$ & $31.9 \pm 5.9$ & $32.1 \pm 5.9$ & $32.1 \pm 5.9$ & $31.5 \pm 6.0$ & $32.2 \pm 5.6$ \\
\hline \multicolumn{7}{|l|}{ HbAlc (\%) } \\
\hline Baseline & $8.5 \pm 1.08$ & $8.3 \pm 0.86$ & $8.4 \pm 0.79$ & $8.3 \pm 0.89$ & $8.1 \pm 0.97$ & $8.2 \pm 0.83$ \\
\hline Individual target & $6.8 \pm 0.46$ & $6.8 \pm 0.45$ & $6.8 \pm 0.42$ & $6.7 \pm 0.42$ & $6.9 \pm 0.58$ & $6.7 \pm 0.46$ \\
\hline $\begin{array}{l}\text { Diabetes duration } \\
\text { (years) }\end{array}$ & $7.8 \pm 6.0$ & $9.0 \pm 6.1$ & $7.4 \pm 5.3$ & $10.8 \pm 6.4$ & $10.9 \pm 7.7$ & $9.0 \pm 6.2$ \\
\hline \multicolumn{7}{|c|}{ Antidiabetic treatment, $n(\%)$} \\
\hline Metformin & $189(76.2)$ & $168(78.1)$ & $94(83.2)$ & $49(79.0)$ & $24(61.5)$ & $122(78.7)$ \\
\hline DPP4 inhibitor & $109(44.0)$ & $100(46.5)$ & $62(54.9)$ & $19(30.6)$ & $18(46.2)$ & $67(43.2)$ \\
\hline SGLT-2 inhibitor & $35(14.1)$ & $32(14.9)$ & $23(20.4)$ & $7(11.3)$ & $2(5.1)$ & $25(16.1)$ \\
\hline Sulfonylurea & $27(10.9)$ & $27(12.6)$ & $11(9.7)$ & $8(12.9)$ & $7(17.9)$ & $23(14.8)$ \\
\hline Glinides & $7(2.8)$ & $6(2.8)$ & $4(3.5)$ & $1(1.6)$ & $1(2.6)$ & $4(2.6)$ \\
\hline $\begin{array}{l}\text { Glucosidase } \\
\text { inhibitors }\end{array}$ & $5(2.0)$ & $5(2.3)$ & $2(1.8)$ & $1(1.6)$ & $2(5.1)$ & $3(1.9)$ \\
\hline GLP-1 analogues & $25(10.1)$ & $19(8.8)$ & $17(15.0)$ & $2(3.2)$ & $0(0.0)$ & $11(7.1)$ \\
\hline \multicolumn{7}{|c|}{ Comorbid conditions, $n(\%)$} \\
\hline Hypertension & $168(67.7)$ & $155(72.1)$ & $74(65.5)$ & $43(69.4)$ & $37(94.9)$ & $113(72.4)$ \\
\hline $\begin{array}{l}\text { Peripheral } \\
\text { Neuropathy }\end{array}$ & $63(25.4)$ & $57(26.5)$ & $25(22.1)$ & $20(32.3)$ & $12(30.8)$ & $44(28.2)$ \\
\hline $\begin{array}{l}\text { Sensory/Motor } \\
\text { Neuropathy }\end{array}$ & $40(16.1)$ & $37(17.2)$ & $18(15.9)$ & $11(17.7)$ & $8(20.5)$ & $31(19.9)$ \\
\hline Microalbuminuria & $43(17.3)$ & $39(18.1)$ & $8(7.1)$ & $10(16.1)$ & $20(51.3)$ & $34(21.8)$ \\
\hline Heart failure & $35(14.1)$ & $31(14.4)$ & $9(8.0)$ & $6(9.7)$ & $16(41.0)$ & $26(16.7)$ \\
\hline $\mathrm{PAD}$ & $16(6.5)$ & $14(6.5)$ & $7(6.2)$ & $5(8.1)$ & $2(5.1)$ & $9(5.8)$ \\
\hline $\begin{array}{l}\text { Diabetic } \\
\text { retinopathy }\end{array}$ & $17(6.9)$ & $16(7.4)$ & $10(8.8)$ & $2(3.2)$ & $3(7.7)$ & $13(8.3)$ \\
\hline
\end{tabular}

Values in table are presented as the mean \pm standard deviation (SD) or as the frequency (number of patients) with the percentage in parentheses

$B M I$ Body mass index, DPP4 dipeptidyl-peptidase 4, FAS full analysis set, GLP glucagon-like peptide 1, HbAIc glycosylated haemoglobin A1c, mFAS12 modified full analysis set with 12 months follow-up, $P A D$ peripheral artery disease, $S A S$ safety analysis set, $S G L T-2$ sodiumglucose co-transporter-2 
Table 2 Dosage of insulin glulisine received over the course of the study

\begin{tabular}{|c|c|c|c|}
\hline FAS & $\begin{array}{l}\text { Insulin } \\
\text { glulisine at } \\
\text { baseline } \\
\text { (visit 1) }\end{array}$ & $\begin{array}{l}\text { Insulin } \\
\text { glulisine } \\
12 \text { months } \\
\text { (visit 5) }\end{array}$ & $p$ value \\
\hline \multicolumn{4}{|l|}{ FAS, dose } \\
\hline $\begin{array}{l}\text { Morning } \\
\text { (units) }\end{array}$ & $8.6 \pm 5.3$ & $12.3 \pm 6.4$ & $<0.0001$ \\
\hline $\begin{array}{l}\text { Lunch } \\
\text { (units) }\end{array}$ & $6.2 \pm 3.2$ & $10.2 \pm 5.5$ & $<0.0001$ \\
\hline $\begin{array}{c}\text { Evening } \\
\text { (units) }\end{array}$ & $7.6 \pm 5.4$ & $11.8 \pm 7.5$ & $<0.0001$ \\
\hline $\begin{array}{l}\text { Total per } \\
\text { day (units) }\end{array}$ & $20.4 \pm 11.8$ & $33.6 \pm 18.1$ & $<0.0001$ \\
\hline \multicolumn{4}{|l|}{$\begin{array}{l}\text { FAS, total } \\
\text { dose by age } \\
\text { group }\end{array}$} \\
\hline $\begin{array}{l}<65 \text { years } \\
\text { (units) }\end{array}$ & $20.3 \pm 12.3$ & $35.1 \pm 20.2$ & 0.0002 \\
\hline $\begin{array}{l}\text { 65-74 years } \\
\text { (units) }\end{array}$ & $20.5 \pm 10.8$ & $32.5 \pm 15.5$ & 0.0012 \\
\hline $\begin{array}{l}\geq 75 \text { years } \\
\text { (units) }\end{array}$ & $20.9 \pm 11.7$ & $31.5 \pm 16.4$ & 0.0189 \\
\hline \multicolumn{4}{|l|}{$\begin{array}{l}\text { mFAS12, } \\
\text { dose }\end{array}$} \\
\hline $\begin{array}{l}\text { Morning } \\
\text { (units) }\end{array}$ & $8.7 \pm 5.3$ & $12.3 \pm 6.5$ & $<0.0001$ \\
\hline $\begin{array}{l}\text { Lunch } \\
\text { (units) }\end{array}$ & $6.3 \pm 3.1$ & $10.2 \pm 5.6$ & $<0.0001$ \\
\hline $\begin{array}{c}\text { Evening } \\
\text { (units) }\end{array}$ & $8.1 \pm 5.9$ & $11.8 \pm 7.5$ & $<0.0001$ \\
\hline $\begin{array}{l}\text { Total per } \\
\text { day (units) }\end{array}$ & $21.1 \pm 12.1$ & $33.6 \pm 18.2$ & $<0.0001$ \\
\hline
\end{tabular}

Values are presented as the mean $\pm S D$

The rate of symptomatic hypoglycaemia was $2.7 \%$ (95\% CI 1.0-5.7) (Table 4), with the rate of confirmed hypoglycaemia being slightly lower
(2.2\%; 95\% CI 0.7-5.1\%). Nocturnal hypoglycaemia was observed at a rate of $0.9 \%$. The rates of severe hypoglycaemia were $0.4 \% \quad(n=1)$, while severe nocturnal hypoglycaemia was not observed. Of the 248 patients, 24 (9.7\%) experienced any AEs (Table 5); in five of these patients, events were considered to be drug-related and four were considered to be serious. During follow-up one patient had a fatal AE (0.4\%; sudden cardiac arrest), but this event was not considered to be drug-related. During the 12-month follow-up, weight and BMI were significantly reduced in the FAS population ($1.5 \pm 6.6 \mathrm{~kg}, p=0.0062$, and $-0.5 \pm 2.24 \mathrm{~kg} /$ $\mathrm{m}^{2}, \quad p=0.0059$, respectively). Patients that completed the 12-month follow-up (mFAS12) were essentially identical to the overall FAS population in terms of age, gender, bodyweight, baseline HbA1c values and drug treatment (Table 1). These patients, however, did have more comorbidities. Treatment target achievement was slightly higher in the mFAS12 (Table 3) than in the FAS. In the former subgroup, $45.2 \%$ of patients achieved their pre-defined treatment goal with an identical mean HbA1c decrease of $1.12 \% \quad(12.2 \mathrm{mmol} / \mathrm{mol}$; $p<0.0001)$. The 7 -point blood glucose profile was again significantly reduced at 12 months and all time-points (Fig. 3; $p<0.0001$ ) with no major difference compared to the FAS. Hypoglycaemic events were nominally lower in patients with a full 12-month follow-up (Table 4 ). AEs in the mFAS12 were only slightly reduced, with lower rates of AEs overall (8.4 vs. $9.7 \%$ ) and drug-related events (0.6 vs. $2.0 \%)$.

\section{Effectiveness and Safety of Insulin Glulisine by Age Group}

Of the 215 patients in the FAS, 113 were aged $<65$ years, 162 were $65-74$ years and 39 were at least 75 years old. There was an increasing proportion of women in the higher age groups $(56.4 \%$ in patients $\geq 75$ years vs. $46.9 \%$ in patients $<65$ years), as well as a longer diabetes duration (10.9 vs. 7.4 years, respectively) and an increased comorbidity profile (Table 1 ). While the baseline HbA1c decreased with age (from $8.4 \%[68.3 \mathrm{mmol} / \mathrm{mol}]$ in patients $<65$ years to 
Table 3 Glycosylated haemoglobin (HbA1c) target achievement, HbAlc at baseline and at 12 months and absolute change in HbAlc overall and by age group

\begin{tabular}{|c|c|c|c|c|c|}
\hline \multirow[t]{2}{*}{ FAS } & \multicolumn{4}{|l|}{ FAS } & \multirow{2}{*}{$\begin{array}{l}\text { mFAS12 } \\
\text { Total }(n=155)\end{array}$} \\
\hline & Total $(n=215)$ & $\begin{array}{l}\text { Patients } \\
<65 \text { years } \\
(n=113)\end{array}$ & $\begin{array}{l}\text { Patients } \\
65-74 \text { years } \\
(n=62)\end{array}$ & $\begin{array}{l}\text { Patients } \\
\geq 75 \text { years } \\
(n=39)\end{array}$ & \\
\hline \multicolumn{6}{|c|}{ HbAlc target achievement $(\%)^{\mathrm{a}}$} \\
\hline 3 months & $12.6(8.2-18.1)$ & $8.2(3.6-15.6)$ & $15.5(7.3-27.4)$ & $20.0(8.4-36.9)$ & $14.1(8.9-20.7)$ \\
\hline 6 months & $22.7(17.1-29.2)$ & $15.8(9.3-24.4)$ & $32.2(20.6-45.6)$ & $27.0(13.8-44.1)$ & $25.2(18.5-32.8)$ \\
\hline 9 months & $30.8(24.5-37.7)$ & $24.8(16.7-34.3)$ & $39.0(26.5-52.6)$ & $35.1(20.2-52.5)$ & $34.8(27.4-42.9)$ \\
\hline 12 months & $38.9(32.1-46.1)$ & $31.7(22.8-41.7)$ & $47.5(34.3-60.9)$ & $45.9(29.5-63.1)$ & $45.2(37.2-53.3)$ \\
\hline \multicolumn{6}{|c|}{ HbAlc change (visit 5 vs. visit 1 ) } \\
\hline $\begin{array}{l}\text { Baseline, \% } \\
{[\mathrm{mmol} / \mathrm{mol}]}\end{array}$ & $8.31[67.3]$ & $8.38[68.1]$ & $8.30[67.2]$ & $8.11[65.1]$ & $8.24[66.6]$ \\
\hline $\begin{array}{c}12 \text { months, \% } \\
{[\mathrm{mmol} / \mathrm{mol}]}\end{array}$ & $7.13[54.4]$ & $7.33[56.6]$ & $6.94[52.3]$ & $6.96[52.6]$ & $7.13[54.4]$ \\
\hline $\begin{array}{l}\text { Change (12 } \\
\text { months vs. } \\
\text { baseline) }^{\mathrm{b}}\end{array}$ & $\begin{array}{l}-1.12 \pm 1.05 \\
\quad[-12.2 \pm 11.5]\end{array}$ & $\begin{array}{l}-1.05 \pm 1.07 \\
{[-11.5 \pm 11.7]}\end{array}$ & $\begin{array}{l}-1.28 \pm 1.04 \\
\quad[-14.0 \pm 11.4]\end{array}$ & $\begin{array}{l}-1.09 \pm 1.03 \\
{[-11.9 \pm 11.3]}\end{array}$ & $\begin{array}{l}-1.12 \pm 1.05 \\
{[-12.2 \pm 11.5]}\end{array}$ \\
\hline $\begin{array}{l}p \text { value for } \\
\text { change vs. } \\
\text { baseline }\end{array}$ & $<0.0001$ & $<0.0001$ & $<0.0001$ & $<0.0001$ & $<0.0001$ \\
\hline
\end{tabular}

${ }^{a}$ Values for HbAlc target achievement are based on number of patients with non-missing values, and are presented as the percentage with the $95 \%$ confidence interval (CI) in parentheses

${ }^{\mathrm{b}}$ Values for HbAlc change (12 months vs. baseline) are presented as the percentage $\pm \mathrm{SD}$, with $\mathrm{mmol} / \mathrm{mol} \pm \mathrm{SD}$ given in square brackets

$8.1 \%[65.0 \mathrm{mmol} / \mathrm{mol}]$ in patients $\geq 75$ years $)$, the individual treatment target remained of the same order of $6.8 \%[50.8 \mathrm{mmol} / \mathrm{mol}]$. Metformin (62.5 vs. $83.2 \%)$ and sodium-glucose cotransporter-2 (SGLT-2) inhibitors (46.2 vs. $54.9 \%$ ) were used less often in the elderly, while sulfonylureas (17.9 vs. 9.7\%) and glucosidase inhibitors (5.1 vs. 1.8\%) were used more often.

On the one hand, increasing age was associated with higher treatment target achievement $(45.9 \%$ in patients $\geq 75$ years vs. $31.7 \%$ in patients $<65$ years at 12 months) (Table 3). This was associated with a lower baseline HbA1c but comparable treatment targets as changes over 12 months were similar in the elderly compared to the youngest. Furthermore, insulin glulisine doses and dose adjustments did not vary substantially with age group. The median time to response was different by age, but showed no consistent age-related pattern (Fig. 2).

On the other hand, there was a steep increase in the risk of hypoglycaemia with age (Table 4). The rate of symptomatic hypoglycaemia was $7.0 \%$ in patients $\geq 75$ years, while it was 1.7 and $1.5 \%$ in patients $<65$ years and $65-74$ years, respectively. A similar pattern was observed for confirmed symptomatic $(0.9,1.5$ and $7.0 \%$, respectively) and nocturnal hypoglycaemia ( 0,0 and $4.7 \%$, respectively). There was also a considerable increase in AEs overall with age. While $6.1 \%$ of all patients aged $<65$ years had an $\mathrm{AE}$, 

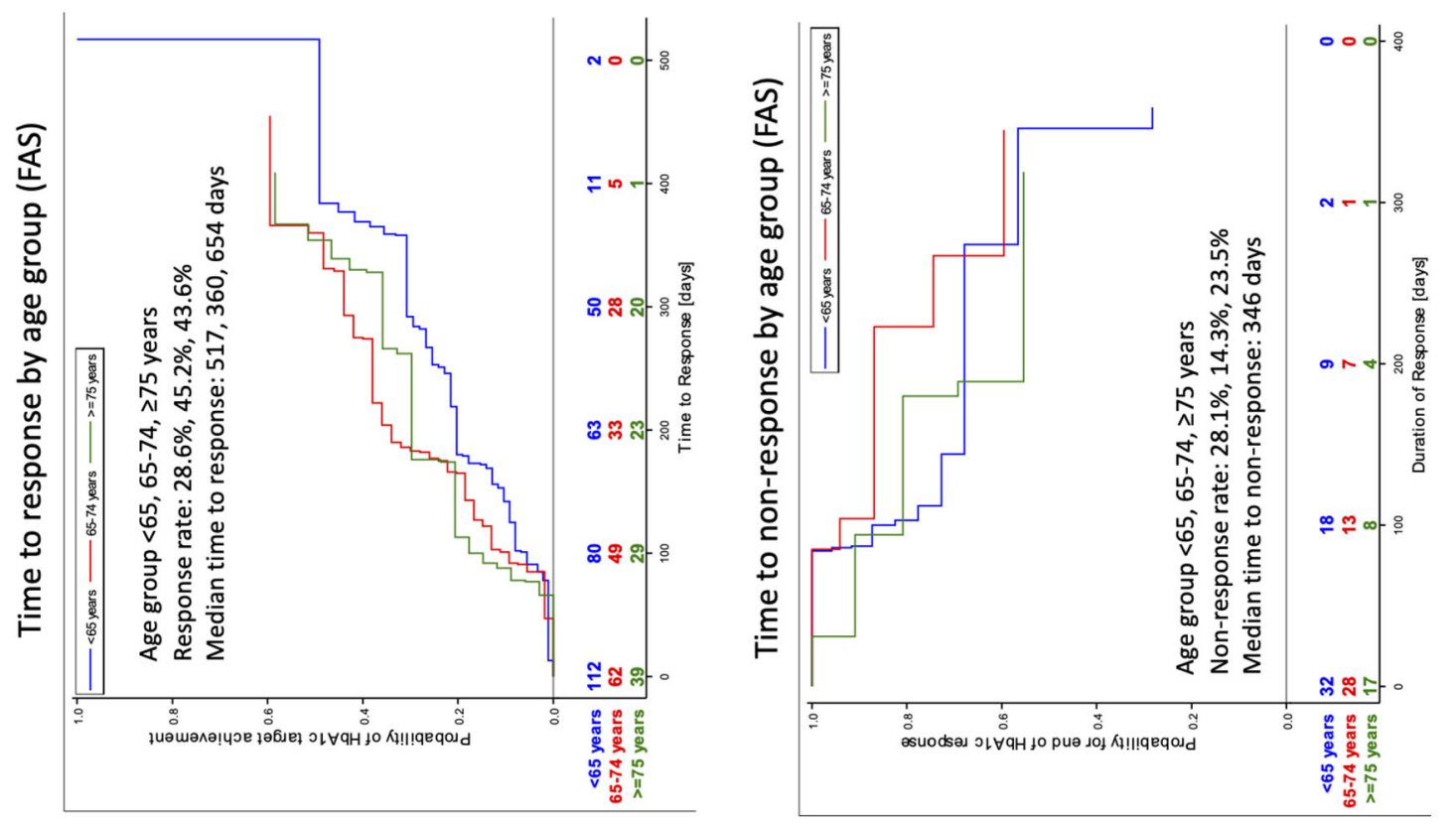

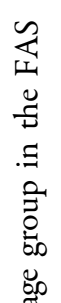
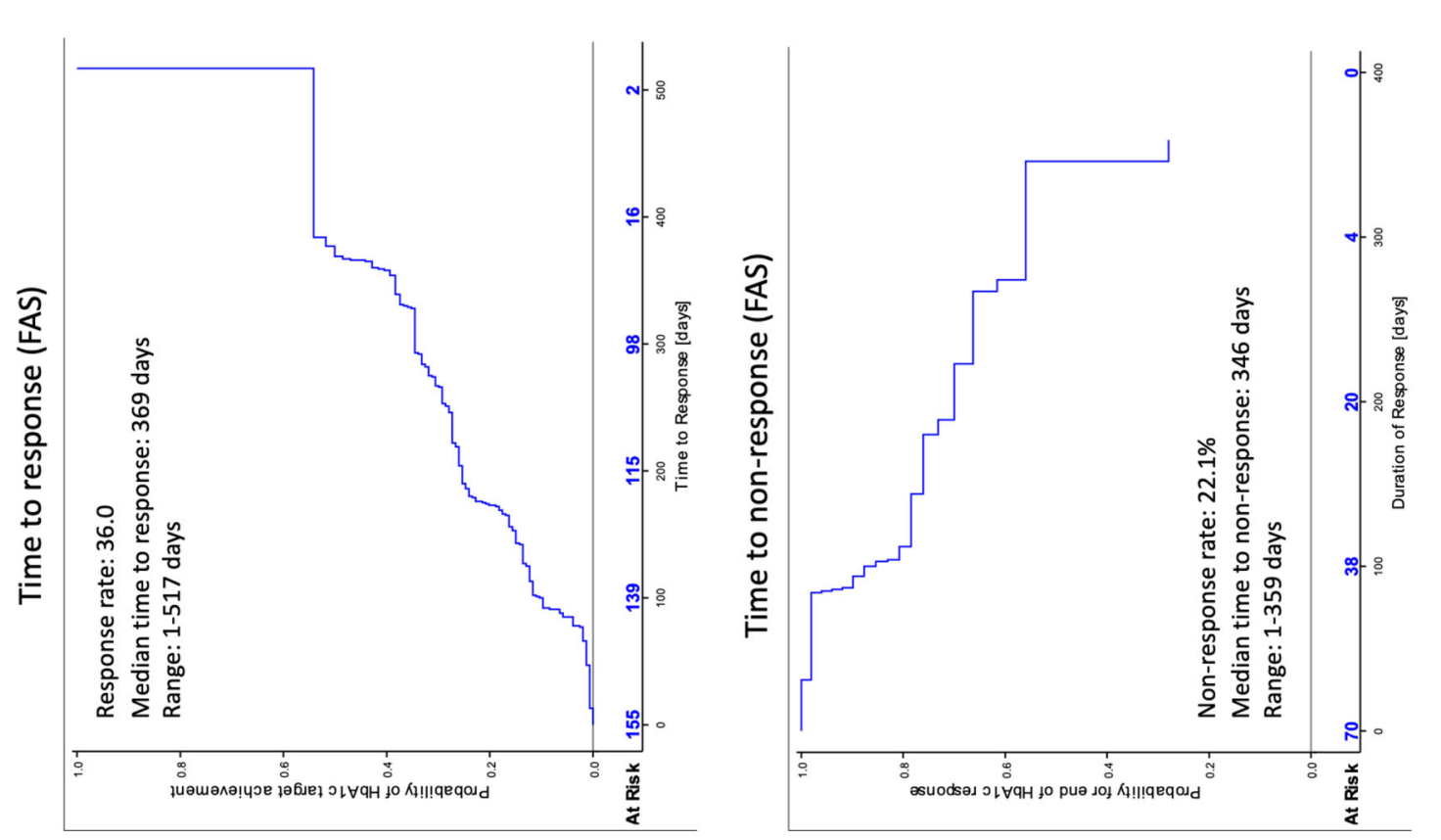

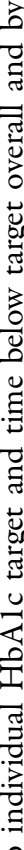

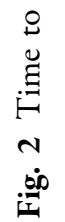


FAS

(a) 300

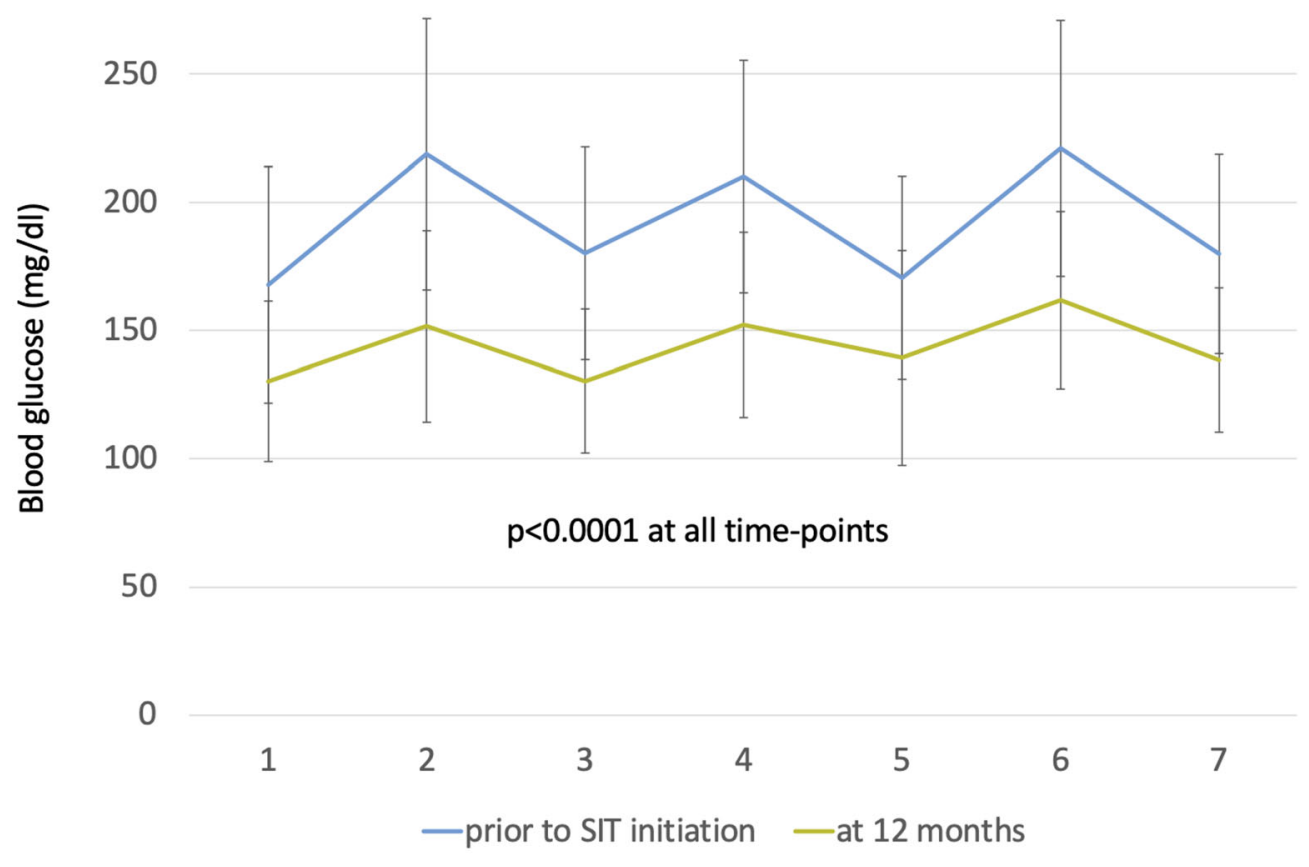

mFAS12

(b) 300

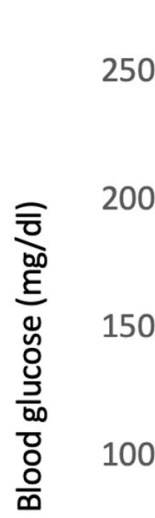

50

$p<0.0001$ at all time-points

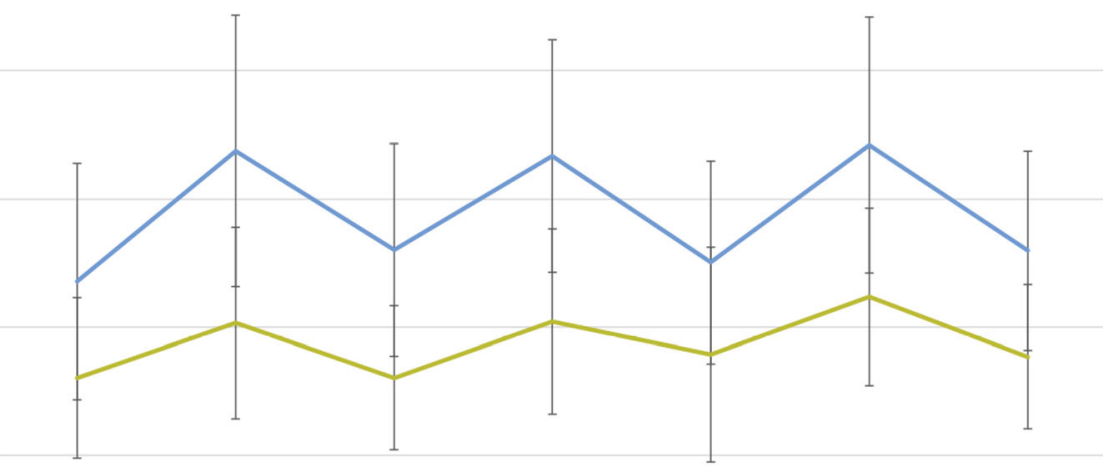

0
1
3
4
5
6
7
— prior to SIT initiation —at 12 months 
4 Fig. 3 Seven-point blood glucose profile in the FAS (a) and mFAS12 (b). 1 Prior to breakfast, $22 \mathrm{~h}$ after breakfast, 3 prior to lunch, $42 \mathrm{~h}$ after lunch, 5 prior to dinner, $62 \mathrm{~h}$ after dinner, 7 bedtime

$17.8 \%$ of those aged $\geq 75$ years had such an event. Rates of serious AEs as well as drug-related events, however, did not differ substantially across age groups.

\section{DISCUSSION}

This was an observational study of patients who had already made the decision to add insulin glulisine to their diabetes therapy and were allowed to continue taking concomitant OADs. Target HbA1c was reached by $38.9 \%$ of patients at 12 months, with higher rates observed in elderly patients ( $\geq 75$ years). Rates of symptomatic hypoglycaemia were low, at $2.7 \%$ overall, but increased with age (up to $7.0 \%$ in patients $\geq 75$ years).

Table 4 Hypoglycaemia

\begin{tabular}{|c|c|c|c|c|c|}
\hline & \multicolumn{4}{|l|}{ SAS } & \multirow{2}{*}{$\begin{array}{l}\text { mFAS12 } \\
\text { Total }(n=155)\end{array}$} \\
\hline & Total $(n=248)$ & $\begin{array}{l}\text { Patients } \\
<65 \text { years } \\
(n=132)\end{array}$ & $\begin{array}{l}\text { Patients } \\
65-74 \text { years } \\
(n=70)\end{array}$ & $\begin{array}{l}\text { Patients } \\
\geq 75 \text { years } \\
(n=45)\end{array}$ & \\
\hline $\begin{array}{l}\text { Symptomatic } \\
\text { hypoglycaemia }\end{array}$ & $2.7(1.0-5.7)$ & $1.7(0.2-6.1)$ & $1.5(0.0-8.3)$ & $7.0(1.5-19.1)$ & $2.6(0.7-6.4)$ \\
\hline $\begin{array}{l}\text { Confirmed sympt. } \\
\text { hypoglycaemia, }\end{array}$ & $2.2(0.7-5.1)$ & $0.9(0.0-4.7)$ & $1.5(0.0-8.3)$ & $7.0(1.5-19.1)$ & $1.9(0.4-5.5)$ \\
\hline $\begin{array}{l}\text { Nocturnal } \\
\text { hypoglycaemia }\end{array}$ & $0.9(0.1-3.2)$ & $0(0.0-3.1)$ & $0(0.0-5.5)$ & $4.7(0.6-15.8)$ & $0.6(0.0-3.5)$ \\
\hline Severe hypoglycaemia & $0.4(0.0-2.5)$ & $0(0.0-3.1)$ & $1.5(0.0-8.3)$ & $0(0.0-8.2)$ & $0.6(0.0-3.5)$ \\
\hline $\begin{array}{l}\text { Severe nocturnal } \\
\text { hypoglycaemia }\end{array}$ & $0.0(0.0-1.6)$ & $0(0.0-3.1)$ & $0(0.0-5.5)$ & $0(0.0-8.2)$ & $0.0(0.0-2.3)$ \\
\hline Rate per patient-year & & & & & \\
\hline $\begin{array}{l}\text { Symptomatic } \\
\text { hypoglycaemia }\end{array}$ & $0.21(0.15-0.29)$ & $0.27(0.18-0.39)$ & $0.02(0.00-0.10)$ & $0.37(0.20-0.62)$ & $0.21(0.15-0.30)$ \\
\hline $\begin{array}{l}\text { Confirmed symptomatic } \\
\text { hypoglycaemia }\end{array}$ & $0.21(0.15-0.28)$ & $0.26(0.17-0.38)$ & $0.02(0.00-0.10)$ & $0.37(0.20-0.62)$ & $0.21(0.14-0.29)$ \\
\hline $\begin{array}{l}\text { Nocturnal } \\
\text { hypoglycaemia }\end{array}$ & $0.03(0.01-0.07)$ & $0.00(0.00-0.04)$ & $0.00(0.00-0.06)$ & $0.16(0.06-0.35)$ & $0.03(0.01-0.06)$ \\
\hline Severe hypoglycaemia & $0.01(0.00-0.03)$ & $0.00(0.00-0.04)$ & $0.02(0.00-0.10)$ & $0.00(0.00-0.10)$ & $0.01(0.00-0.03)$ \\
\hline $\begin{array}{l}\text { Patients with severe } \\
\text { nocturnal } \\
\text { hypoglycaemia }\end{array}$ & $0.00(0.00-0.02)$ & $0.00(0.00-0.04)$ & $0.00(0.00-0.06)$ & $0.00(0.00-0.10)$ & $0.00(0.00-0.02)$ \\
\hline
\end{tabular}

Values are presented as the percentage of patients with the $95 \% \mathrm{CI}$ in parentheses 
Table 5 Adverse events in safely analysis set

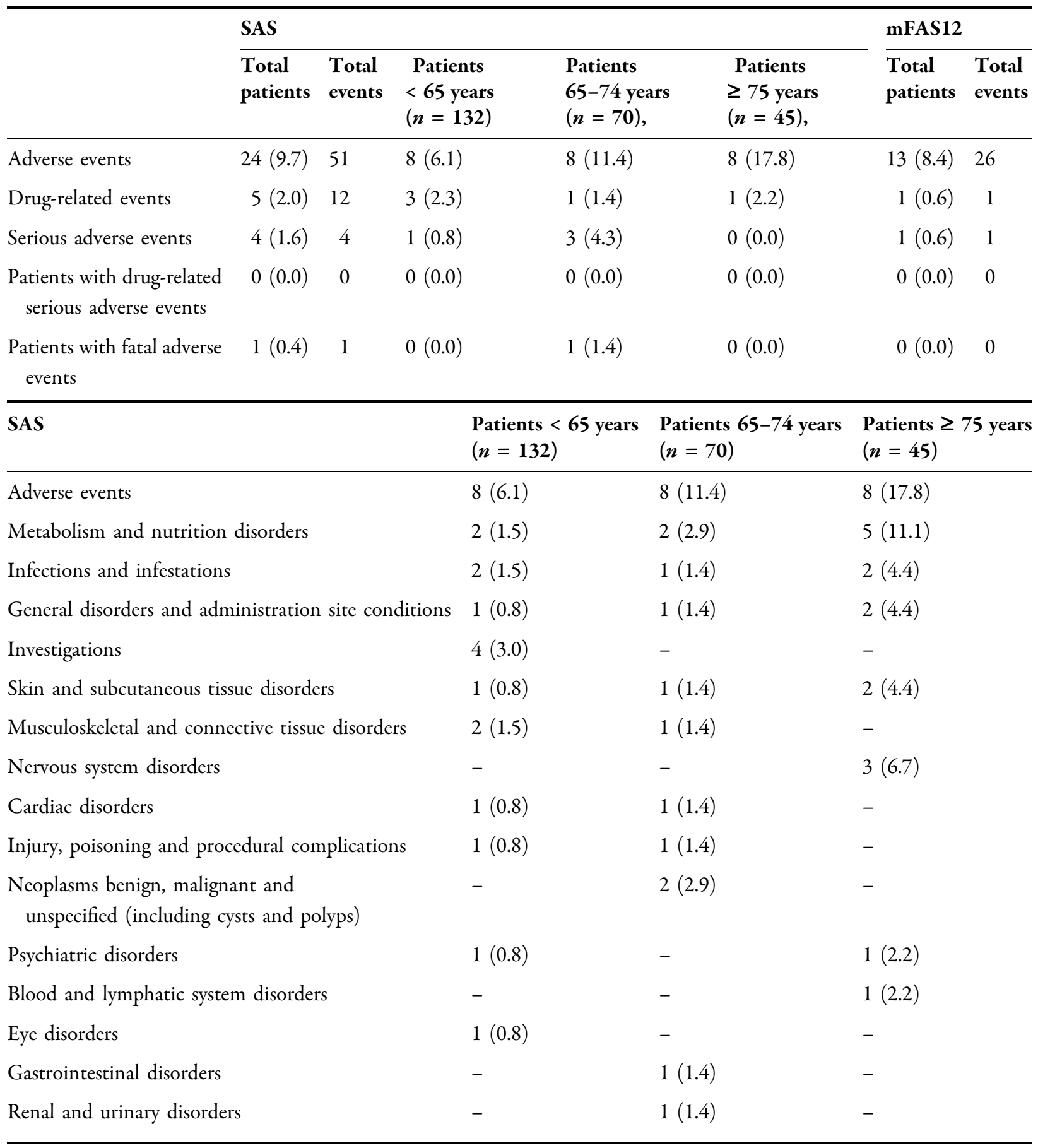

Values in table are presented as the number $(n)$ with/without the percentage in parentheses 


\section{Effectiveness and Safety of Insulin Glulisine}

Both BOT and SIT are viable treatment options when OADs fail to provide sufficient blood glucose control. While BOT may appear to be a little less effort for patients, patients using SIT are more flexible and do not need to adhere to fixed mealtimes because there is no basal insulin acting during the course of the day that requires daily carbohydrate intake. Furthermore, the patient administers the required insulin dose shortly before the meal. The rapidacting insulin will, when required, correct an actual blood glucose elevation and prevent a mealtime-associated increase in blood sugar. As such, the present study provides data for the clinical effectiveness and safety of SIT in T2DM patients in Germany.

The SIT concept is based on a few studies conducted using different rapid-acting insulin analogues or regular human insulin showing that the (early) administration of rapid-acting insulin will allow the beta-cell function to recover and may provide a more flexible treatment regimen compared to a BOT regimen. Pfützner et al. [8] showed that supplementary insulin aspart treatment resulted in beta-cell protection with an improved fasting beta-cell secretion profile within 1 week. Kawamori et al. [9] reported that insulin glulisine, given either alone or in combination with OADs (most frequently metformin and sulfonylurea), provided superior reductions in HbA1c compared to an oral treatment alone, but at the cost of (mostly non-severe) hypoglycaemia. Finally, Chlup et al. [10] compared insulin aspart with regular human insulin and other insulin analogues in 57 patients with T2DM in an observational setting. Following a switch from regular human insulin to aspart, HbA1c decreased by $0.6 \%$ $(6.6 \mathrm{mmol} / \mathrm{mol})$ within 1 year while rates of hypo- and hyperglycaemia did not change.

The results of the aforementioned studies are well in line with the results of the present study. In our study using insulin glulisine, the HbA1c was reduced by $1.12 \%(12.2 \mathrm{mmol} / \mathrm{mol})$ over the course of 1 year, resulting in $38.9 \%$ of the patients meeting their pre-specified HbA1c treatment goal. Rates of symptomatic hypoglycaemia were $2.7 \% \quad(2.2 \%$ confirmed symptomatic hypoglycaemia), and only one patient suffered from severe hypoglycaemia.

\section{Effectiveness and Safety of Insulin Glulisine by Age Group}

To our knowledge, there have not been any prior analyses of the benefits and risks of SIT in different age groups. Our analyses were driven by the perception that elderly patients may represent a distinct patient group in which comorbidity, a decline in kidney function and mental fitness may play a substantial role. Recent guidelines have correctly emphasised the specific needs of elderly patients and proposed that they may not need to meet as stringent blood glucose targets as younger patients [5-7] to achieve an optimised patient-individual treatment target.

In our study, treatment target attainment was higher in elderly patients than in younger patients. As baseline HbA1c values were lower in elderly patients $(8.1$ vs. $8.4 \%$ [65.0 vs. $68.3 \mathrm{mmol} / \mathrm{mol}]$ ) and treatment targets slightly less stringent $(6.9$ vs. $6.8 \% \quad[51.9$ vs. $50.8 \mathrm{mmol} / \mathrm{mol}])$, the distance to target was reduced in the elderly patients (1.2 vs. $1.6 \%$ [13.1 vs. $17.5 \mathrm{mmol} / \mathrm{mol}]$ ). This may reasonably translate into increased treatment target achievement in the elderly as insulin glulisine doses were only slightly lower (total daily dose 31.5 units in patients $\geq 75$ years vs. 35.1 units in patients $<65$ years).

Rates of hypoglycaemia, on the other hand, were higher in elderly patients, with $7.0 \%$ suffering from symptomatic hypoglycaemia in the group of elderly patients versus $1.7 \%$ in patients $<65$ years. These episodes, however, were never severe, and many of them were documented during the night (nocturnal hypoglycaemia). This observation is in principal in agreement with prior research [11] and with a subgroup analysis of the ACCORD Study which showed that each year of lifetime increased the risk for hypoglycaemia $(p<0.0001)$ [12], although the study did not look into the effects of supplementary insulin therapy. 
Potential reasons for the observed increased hypoglycaemia risk include the increased comorbidity burden of elderly patients, a decline in renal function and a higher rate of mental impairment. With respect to renal function decline, Urata et al. [13] have recently shown that insulin glulisine is advantageous over regular human insulin in the treatment of patients with diabetes and severe renal insufficiency. The role of dementia and a subsequently reduced medication adherence was recently emphasised by Holstein and Prinz in two observational studies including patients with T2DM [14, 15]. It appears, therefore, that a careful routine assessment of risk factors for an imbalance of glycaemic control and hypoglycaemia is necessary in elderly patients [16]. Encouraging training programmes and the use of continuous glucose monitoring systems may substantially reduce the risk of hypoglycaemia $[7,17,18]$.

\section{Limitations}

The value of observational research is frequently challenged, based on the notion that randomised research is virtually free of bias unlike observational studies. The intervention in a randomised controlled trial usually only covers part of the patient population that is being treated in clinical practice and, therefore, is only partially able to address the challenges faced in daily practice. As such, the present study provides data on the value of SIT up and beyond a confined clinical research study. The design, however, is not suitable for comparing different treatment strategies over time without physician and patient bias, and intentional or unknown concomitant changes to the treatment approach may interfere with the observed result. In general, insulin glulisine is administered with the main meals (breakfast, lunch and dinner), and these are the time points that physicians were asked to complete the insulin doses in our electronic case report form. However, physicians may opt for once- or twicedaily short-acting insulins, but this was not the focus of this current study. Finally, patient-reported outcomes and treatment satisfaction are important considerations for any diabetic medication and while outside the scope of our study, they do warrant investigation.

\section{CONCLUSIONS}

Initiating SIT with insulin glulisine is a potential treatment option in insufficiently controlled patients with T2DM. Particular attention should be paid to elderly patients in whom higher rates of treatment target attainment were associated with higher rates of hypoglycaemia and AEs.

\section{ACKNOWLEDGEMENTS}

The contribution of all centres and patients providing data for the present analysis is acknowledged.

Funding. The study was sponsored by Sanofi-Aventis Deutschland GmbH. The statistician was paid by Sanofi, with the steering board (equivalent to the author group) advising on the performance and evaluation of this study. The sponsor also funded the journal's Rapid Service Fee.

Authorship. All named authors meet the International Committee of Medical Journal Editors (ICMJE) criteria for authorship for this article, take responsibility for the integrity of the work as a whole, and have given their approval for this version to be published.

Authorship Contributions. Martin Pfohl (MP), Jochen Seufert (JS), Anja Borck (AB) and Thorsten Siegmund (TS) made substantial contributions to the conception and design of the study. MP, JS, AB, Peter Bramlage (PB) and TS made substantial contributions to the acquisition of data, or analysis and interpretation of data. MP and $\mathrm{PB}$ were involved in drafting the manuscript, and JS, AB and TS revised it critically for important intellectual content. MP, JS, $\mathrm{AB}, \mathrm{PB}$ and $\mathrm{TS}$ gave final approval of the version to be published, take public responsibility and 
can be held accountable for all aspects of the work.

Disclosures. MP: Member of Scientific Advisory Boards of Boehringer Ingelheim, Eli Lilly, Novo Nordisk and Sanofi; received honoraria for talks from Eli Lilly, Novartis, Novo Nordisk and Sanofi. JS received honoraria for talks and/ or consultancy and/or research funding from Abbott, Astra Zeneca, Bayer, Berlin Chemie, Boehringer Ingelheim, Bristol Myers Squibb (BMS), GI-Dynamics, Glaxo Smith Kline, Intarcia, Ipsen, Janssen, LifeScan, Lilly, Merck Sharp Dohme (MSD), MedScape, Mundipharma, Novartis, NovoNordisk, Omniamed, Pfizer, Roche, Sanofi Aventis, Servier, Takeda and Ypsomed. AB is an employee of Sanofi. PB: Honoraria for consultancy from Sanofi-Aventis, MSD, AstraZeneca, BMS, Boehringer Ingelheim, Novartis, Pfizer. TS: Honoraria for talks and/or consultancy and/or research funding from Abbott, Ascensia, Astra Zeneca, Bayer, Becton Dickinson, Berlin Chemie, Biogen, Boehringer Ingelheim, Janssen, Medtronic, Lilly, MSD, Novartis, NovoNordisk, Roche and Sanofi Aventis.

Compliance with Ethics Guidelines. The registry protocol was approved by the University of Freiburg, Germany, and was carried out in accordance with the Declaration of Helsinki and its amendments. Only subjects who provided written informed consent to participate were included in this study. Patient consent for publication was not required.

Data Availability. The datasets generated during and/or analysed during the current study are available from the corresponding author on reasonable request.

Open Access. This article is licensed under a Creative Commons Attribution-NonCommercial 4.0 International License, which permits any non-commercial use, sharing, adaptation, distribution and reproduction in any medium or format, as long as you give appropriate credit to the original author(s) and the source, provide a link to the Creative Commons licence, and indicate if changes were made. The images or other third party material in this article are included in the article's Creative Commons licence, unless indicated otherwise in a credit line to the material. If material is not included in the article's Creative Commons licence and your intended use is not permitted by statutory regulation or exceeds the permitted use, you will need to obtain permission directly from the copyright holder. To view a copy of this licence, visit http://creativecommons.org/licenses/bync/4.0/.

\section{REFERENCES}

1. Arnolds S, Rave K, Hovelmann U, Fischer A, SertLangeron $\mathrm{C}$, Heise $\mathrm{T}$. Insulin glulisine has a faster onset of action compared with insulin aspart in healthy volunteers. Exp Clin Endocrinol Diabetes. 2010;118(9):662-4.

2. Bolli GB, Luzio S, Marzotti S, et al. Comparative pharmacodynamic and pharmacokinetic characteristics of subcutaneous insulin glulisine and insulin aspart prior to a standard meal in obese subjects with type 2 diabetes. Diabetes Obes Metab. 2011;13(3):251-7.

3. Philotheou A, Arslanian S, Blatniczky L, Peterkova V, Souhami E, Danne T. Comparable efficacy and safety of insulin glulisine and insulin lispro when given as part of a basal-bolus insulin regimen in a 26-week trial in pediatric patients with type 1 diabetes. Diabetes Technol Ther. 2011;13(3):327-34.

4. Davies MJ, D'Alessio DA, Fradkin J, et al. Management of Hyperglycemia in Type 2 Diabetes, 2018. A Consensus Report by the American Diabetes Association (ADA) and the European Association for the Study of Diabetes (EASD). Diabetes Care. 2018;41(12):2669-701.

5. Rydén L, Grant PJ, Anker SD, et al. ESC Guidelines on diabetes, pre-diabetes, and cardiovascular diseases developed in collaboration with the EASD: the Task Force on diabetes, pre-diabetes, and cardiovascular diseases of the European Society of Cardiology (ESC) and developed in collaboration with the European Association for the Study of Diabetes (EASD). Eur Heart J. 2013;34(39):3035-87.

6. Cho NH, Colagiuri S, Distiller L, et al. Managing older people with type 2 diabetes global guideline. International Diabetes Federation; 2013. https:// www.idf.org/e-library/guidelines/78global-guideline -for-managing-older-people-with-type-2diabetes. html. Accessed 10 Nov 2020. 
7. German Diabetes Association. S2k-Leitlinie Diagnostik, Therapie und Verlaufskontrolle des Diabetes mellitus im Alter. AWMF-Registernummer: 057-017. 2018. https://www.deutsche-diabetes-gese llschaft.de/fileadmin/Redakteur/Leitlinien/Evidenz basierte_Leitlinien/2018/057_017_LL_Alter_Gesamt dokument_20180713.pdf. Accessed 10 Nov 2020.

8. Pfutzner A, Lorra B, Abdollahnia MR, et al. The switch from sulfonylurea to preprandial short- acting insulin analog substitution has an immediate and comprehensive beta-cell protective effect in patients with type 2 diabetes mellitus. Diabetes Technol Ther. 2006;8(3):375-84.

9. Kawamori R, Iwamoto Y, Kadowaki T, et al. Effects of insulin glulisine as mono- or add-on therapy in patients with type 2 diabetes mellitus. Diabetes Obes Metab. 2009;11(9):900-9.

10. Chlup R, Zapletalova J, Seckar P, et al. Benefits of complementary therapy with insulin aspart versus human regular insulin in persons with type 2 diabetes mellitus. Diabetes Technol Ther. 2007;9(3): 223-31.

11. Bramlage P, Gitt AK, Binz C, Krekler M, Deeg E, Tschope D. Oral antidiabetic treatment in type-2 diabetes in the elderly: balancing the need for glucose control and the risk of hypoglycemia. Cardiovasc Diabetol. 2012;11:122.

12. Miller ME, Bonds DE, Gerstein HC, et al. The effects of baseline characteristics, glycaemia treatment approach, and glycated haemoglobin concentration on the risk of severe hypoglycaemia: post hoc epidemiological analysis of the ACCORD study. BMJ. 2010;340:b5444.

13. Urata H, Mori K, Emoto $M$, et al. Advantage of insulin glulisine over regular insulin in patients with type 2 diabetes and severe renal insufficiency. J Ren Nutr. 2015;25(2):129-34.

14. Holstein A, Patzer OM, Machalke K, Holstein JD, Stumvoll M, Kovacs P. Substantial increase in incidence of severe hypoglycemia between 1997-2000 and 2007-2010: a German longitudinal populationbased study. Diabetes Care. 2012;35(5):972-5.

15. Prinz N, Stingl J, Dapp A, et al. High rate of hypoglycemia in 6770 type 2 diabetes patients with comorbid dementia: a multicenter cohort study on 215,932 patients from the German/Austrian diabetes registry. Diabetes Res Clin Pract. 2016;112: 73-81.

16. American Diabetes Association. 11. Older adults: standards of medical care in diabetes-2018. Diabetes Care. 2018;41(Suppl 1):S119-25.

17. Bahrmann A, Wörz E, Specht-Leible N, Oster P, Bahrmann P. Diabetes care and incidence of severe hypoglycemia in nursing home facilities and nursing services: the Heidelberg Diabetes Study. Z Gerontol Geriatr. 2015;48(3):246-54.

18. Silbert R, Salcido-Montenegro A, Rodriguez-Gutierrez R, Katabi A, McCoy RG. Hypoglycemia among patients with type 2 diabetes: epidemiology, risk factors, and prevention strategies. Curr Diab Rep. 2018;18(8):53. 